\title{
Elementary, Chemical and Energy Characterization of "Dendê" (Elaeis guineensis Jacq.) Waste in the State of Pará
}

\author{
Jesomi Jonatan da Costa Abreu $^{1}$ (D), Cleibiane da Silva Martins ${ }^{2}$ (D), \\ Paulo Cezar Gomes Pereira ${ }^{3}$ (D), Maria Lucia Bianchi ${ }^{4}$ (D), \\ João Rodrigo Coimbra Nobre ${ }^{5}$ (D) \\ ${ }^{1}$ Universidade Federal de Santa Maria - UFSM, Santa Maria/RS, Brasil \\ ${ }^{2}$ Universidade do Estado de Santa Catarina - UDESC, Lages/SC, Brasil \\ ${ }^{3}$ Universidade Federal Rural da Amazônia - UFRA, Paragominas/PA, Brasil \\ ${ }^{4}$ Universidade Federal de Lavras - UFLA, Lavras/MG, Brasil \\ ${ }^{5}$ Departamento de Tecnologia da Madeira - DETM, Universidade do Estado do Pará - UEPA, Paragominas/PA, Brasil
}

\begin{abstract}
This work aimed to chemically and energetically characterize palm waste in the municipality of Igarapé Açú-PA. The residue was crushed, sieved and acclimated up to $12 \%$ of humidity. Chemical analyses were performed in the fresh material, according to NBR standards. Part of the residue was transformed into charcoal at $450^{\circ} \mathrm{C}$, with heating rate of $1.67^{\circ} \mathrm{C} \cdot \mathrm{min}^{-1}$ and residence time of 30 minutes. Elementary analysis (CHNS-O) was carried out in the fresh and carbonized material. For biomass, means of $32.67 \%$ of lignin and $2.58 \%$ of minerals were found. Means of $79.71 \%$ for volatile materials and $9.85 \%$ for fixed carbon were also found. In the elementary analysis, mean values of $53.79 \%$ for carbon and $0.7 \%$ for sulfur were found. Palm biomass residues presented high fixed carbon, structural carbon and lignin levels, thus presenting potential to be used in the direct production of energy, activated carbon and also biochar.
\end{abstract}

Keywords: biomass, fixed carbon, lignin, energy. 


\section{INTRODUCTION}

The growing search for new types of renewable energies has encouraged researchers to bring the use of agricultural residues, that is, biomass to generate energy as a new research theme (Souza et al., 2011). Biomass is defined as any organic matter of animal or vegetable origin that can be transformed and provide energy, either as heat or electricity (Saidur et al., 2011). Biochar, which is an enriched porous material and produced from a variety of biomasses, is among products that can be obtained. Palm is an oilseed with high productivity, which can supply 4 to 6 tons of oil per hectare annually, while coconut produces 3 tons, olive 2 tons, peanut 1.2 tons and soybean 0.6 ton of oil per ha (Hameed Khan \& Krishnakumar, 2018). Palm oil is applied as raw material for different segments in the food, soap and cosmetics, chemical and pharmaceutical industries. It is a permanent crop that begins its production in the third year after planting, reaches maximum productivity from the eighth year, and can be economically exploited for twenty years. It is produced throughout the year, without problems of seasonal crops, allowing manpower occupation every month of the year. The evolution of palm oil production in the state of Pará has been outstanding in the last ten years. The objective of this work was to perform the elementary, chemical and energetic characterization of the palm biomass for indication of use.

\section{MATERIAL AND METHODS}

Palm residue was collected in the municipality of Igarapé Açú-PA, consisting of dendê pie, obtained from the processing to remove oil and olive oil. Some of the material was stored in identified plastic bags, then crushed and sieved in sieves with grain size of 40, 60, 100, 200 and 270 mesh. Materials classified by granulometry were stored in air conditioning room, with temperature conditions of $20 \pm 2{ }^{\circ} \mathrm{C}$ and humidity of $65 \pm 3 \%$, until reaching constant mass, with humidity of $12 \%$. The other part of the fresh material was only acclimated after the charring process.

Biomass was dried at $12 \%$ of moisture and transformed into charcoal at temperature of $450{ }^{\circ} \mathrm{C}$, with heating rate of $1.67{ }^{\circ} \mathrm{Cmin}^{-1}$ and residence time of 30 minutes, being naturally and gradually cooled

until furnace reaches final carbonization temperature and time. For the elementary analysis (CHNS), the fraction retained in the 270 mesh screen indicated for analysis was used.

Chemical analyses for the quantification of lignin, total secondary (extractive) components and inorganic (mineral) constituents of materials were performed according to standards listed in Table 1, using Elemental universal analyzer - model Vario Micro Cube.

The analyzer uses helium and oxygen as drag and ignition gases, respectively. The 2 -mg and three replicate samples for each biomass were packed in tin capsules and completely incinerated at $1200^{\circ} \mathrm{C}$. The holocellulose content was determined by difference in relation to the other chemical constituents as total extractives, lignin and minerals. The chemical characterization of charcoals and biomass was carried out according to procedures described by Moulin et al. (2017). All chemical analyses were carried out in triplicates to calculate the mean values, standard deviation and variation coefficient and values were obtained in the form of descriptive statistics.

\section{RESULTS AND DISCUSSION}

The lignin content of palm biomass was 32.67\% (Table 2). According to Brito \& Barrichelo (1977) and Castro (2016), high lignin contents may be correlated with higher fixed carbon content, volatile substances and consequently higher gravimetric coal yield.

Esteves et al. (2015) found mean values of $30.6 \%$ lignin, $3.7 \%$ extractives and $62.5 \%$ holocellulose for coconut shell biomass, values that differ slightly from those found for palm oil. It is known that the increase in lignin content leads to an increase in coal production, in contrast to the increase in holocellulose content, which causes a decrease in yield, since almost all this component has thermal degradation between 200 and $350{ }^{\circ} \mathrm{C}$, and charcoal is produced at temperatures above $400{ }^{\circ} \mathrm{C}$ (Vale et al., 2010). Nevertheless, the presence of lignin is quite satisfactory

Table 1. Standards used for chemical analysis of materials.

Chemical tests

Total Extracts - EXT. (\%) NBR 14853/2010 (ABNT, 2010a) Insoluble lignin - LIG. (\%) NBR 7989/2010 (ABNT, 2010b)

Minerals - MIN. (\%) NBR 13999/2003 (ABNT, 2003) 
in Elaeis guineensis Jacq. residues and depending on its use, it may not harm charcoal production. It is worth mentioning that the variation in the values of the smaller, extractive and mineral constituents can be explained by the influence of genetic factors and soil composition. Yang et al. (2006) studied the influence of mineral materials on the pyrolysis of palm oil residues and observed that coal yield decreased with low mineral content.

The values obtained for the chemical composition of biomass (moisture, volatile materials, fixed carbon and ashes) are exhibited in Table 3.

It was observed that the mean moisture content of palm oil residues is low (7.97\%) compared to other results found for apple pruning $(37.66 \%)$ and coffee beans and bark residues (15.66\%) (Vale et al., 2007; Ekinci, 2011). According to Luk et al. (2013), when it comes to samples for the generation of energy, high value for this parameter is not interesting, thus confirming an advantage of palm oil residues for energy use, being also considered an essential factor in the coal vegetable production.
Values of $9.85 \%$ for fixed carbon, $79.71 \%$ for volatiles and $2.47 \%$ for ashes were also found, data very close to those found by Teixeira (2008) for babassu biomass of 9.62\% for fixed carbon, $88.16 \%$ for volatiles and ashes (2.22\%). According to Brito \& Barrichelo (1977), high lignin values are statistically correlated with higher levels of fixed carbon, volatile substances, ashes and volumetric coal yield, thus making the results found in this work consistent with literature.

In Table 4, elementary biomass analysis showed carbon content of $53.79 \%$, characteristic of material adequate for the production of activated carbon. Similar results were observed by other authors when studying residual biomass of soybean, olive pomace, olive stone, black acacia bark and residual biomass of the Amazon (Linhares et al., 2016; Castro, 2016; Demiral et al., 2011; Tay et al., 2009).

Values of elementary analysis (CHNS-O) of palm charcoal produced at temperature of $450{ }^{\circ} \mathrm{C}$ can be observed in Table 5.

It was observed that, in the produced carbon, carbon contents are higher and hydrogen contents are lower

Table 2. Mean values of chemical composition, standard deviation (DP) and variation coefficient (VC) of Elaeis guineensis Jacq. residues.

\begin{tabular}{|c|c|c|c|c|c|}
\hline \multirow{2}{*}{ Species } & & \multicolumn{4}{|c|}{ Chemical composition (\%) } \\
\hline & & Lignin & Extractives & Minerals & Holocellulose* \\
\hline \multirow{3}{*}{ Palm } & Mean & 32.67 & 24.92 & 2.58 & 39.83 \\
\hline & DP & 0.60 & 0.21 & 0.15 & 1.19 \\
\hline & $\mathrm{CV}$ & 1.84 & 0.84 & 5.81 & 2.99 \\
\hline
\end{tabular}

${ }^{*}$ Value obtained by difference; $\mathrm{DP}=$ standard deviation; $\mathrm{VC}=$ variation coefficient.

Table 3. Moisture and immediate chemical composition of Elaeis guineensis Jacq. residues.

\begin{tabular}{lccccc}
\multirow{2}{*}{ Species } & & \multicolumn{4}{c}{ Composition (\%) } \\
\cline { 3 - 6 } & & Moisture & Volatile & Ashes & Fixed Carbon* $^{*}$ \\
\multirow{3}{*}{ Palm } & Mean & 7.97 & 79.71 & 2.47 & 9.85 \\
& SD & 0.33 & 0.43 & 0.12 & 0.46 \\
\hline
\end{tabular}

${ }^{*}$ Value obtained by difference; $\mathrm{SD}=$ standard deviation; $\mathrm{VC}=$ variation coefficient.

Table 4. Mean values of elementary analysis, standard deviation (DP) and variation coefficient (VC) for Elaeis guineensis Jacq. biomass.

\begin{tabular}{|c|c|c|c|c|c|c|c|}
\hline \multirow{2}{*}{ Species } & & \multicolumn{5}{|c|}{ Elements (\%) } & \multirow{2}{*}{$\mathrm{O} / \mathrm{C}$} \\
\hline & & $\mathrm{C}$ & $\mathbf{H}$ & $\mathbf{N}$ & $S$ & $\mathbf{O}^{*}$ & \\
\hline \multirow{3}{*}{ Palm } & Mean & 53.79 & 6.71 & 1.96 & 0.07 & 35.00 & 0.65 \\
\hline & $\mathrm{SD}$ & 0.54 & 0.07 & 0.13 & 0.01 & 0.68 & 0.02 \\
\hline & VC & 1.00 & 1.04 & 6.63 & 14.3 & 1.94 & 3.08 \\
\hline
\end{tabular}

*Values obtained by difference among the other constituents, discounting the amount of minerals of the immediate composition (Table 3); $\mathrm{SD}=$ standard deviation; $\mathrm{VC}=$ variation coefficient. 
when compared to the original biomass (Table 4), further emphasizing the high quality of the coal obtained. In the case of pyrolysis, it is possible to obtain a product with high carbon content due to the volatilization of hydrogen, oxygen and nitrogen-containing compounds (Sekirifa et al., 2013). According to Oasmaa et al. (2010), biomasses with less lignin and more hemicelluloses and ash contents present higher $\mathrm{O} / \mathrm{C}$ ratios, since lignin has $30 \%$ oxygen and $65 \%$ of elemental carbon in its composition, whereas other polymers have about $50 \%$ oxygen and $45 \%$ carbon. In addition, Huang et al. (2009) reported that the quantification of elemental chemical components is important in the characterization of solid biofuel because the energy released during the combustion process is positively correlated with carbon and hydrogen contents and, contrary to the oxygen content.

According to Hamza et al. (2016) and Machado \& Andrade (2004), for methodological reasons, the coal elemental chemical analysis results in an increase in the carbon content in relation to the immediate chemical analysis, due to the first accounting for both the free carbons, which later constitute the volatile materials, as well as those that are part of the coal chemical structure. It was also observed that the elemental carbon contents were higher than those observed for the fixed carbon content (Table 6).

It should be noted that the moisture value was $4.56 \%$, which is a very favorable result, because the lower the index, the higher the quality of the produced charcoal, providing rapid combustion process and increased carbonization yield. For Brand \& Giesel (2017), the high moisture content present in biomass makes it difficult to use it directly, that is, humidity reduces the amount of energy produced during combustion. Regarding the composition of volatiles (22.09\%), it was estimated that this result was low in comparison to the presence of fixed carbon, which was quite high (70.18\%). For Trugilho \& Silva (2001) and Protásio et al. (2011), the higher the fixed carbon content and the lower the content of volatiles of charcoal, the higher its caloric value, thus demonstrating the great energetic potential of charcoal from palm biomass.

The ash and fixed carbon contents were $3.17 \%$ and $70.18 \%$, respectively. According to Soares et al. (2014), ashes are considered undesirable in the coal production process, because these are combustion residues responsible for the emission of metals due to their composition, that is, high ash concentration negatively affects the calorific value and the heat transfer. However the fixed carbon content helps in the development of coal pores in the pyrolysis process (Hamza et al., 2016). Thus, raw materials with higher carbon and lower ash contents may be considered more suitable for the production of activated carbon (Cheng et al., 2016).

It was verified that the charcoal obtained was homogeneous due to the lower standard deviation and variation coefficient values, which ultimately characterize high quality final product. In this sense, the search for superior genetic material in favor of charcoal production is essential to increase the yield

Table 5. Mean values of elementary analysis, standard deviation (SD) and variation coefficient (VC) of coal at carbonization temperature of $450^{\circ} \mathrm{C}$.

\begin{tabular}{|c|c|c|c|c|c|c|c|}
\hline \multirow{2}{*}{ Charcoal } & & \multicolumn{6}{|c|}{ Elements (\%) } \\
\hline & & C & $\mathbf{H}$ & $\mathbf{N}$ & $\mathbf{S}$ & $\mathbf{O}^{*}$ & $\mathrm{O} / \mathrm{C}$ \\
\hline \multirow{3}{*}{ Palm } & Mean & 70.43 & 3.41 & 3.45 & 0.10 & 20.14 & 0.29 \\
\hline & $\mathrm{SD}$ & 0.09 & 0.01 & 0.02 & 0.00 & 0.08 & 0.00 \\
\hline & VC & 0.13 & 0.29 & 0.58 & 0.00 & 0.40 & 0.00 \\
\hline
\end{tabular}

${ }^{*}$ Values obtained by difference among the other constituents, discounting the amount of minerals of the immediate composition (Table 3); SD = standard deviation; VC = variation coefficient.

Table 6. Moisture and immediate chemical composition of charcoal produced from Elaeis guineensis Jacq. Biomass.

\begin{tabular}{lccccc}
\multirow{2}{*}{ Charcoal } & & \multicolumn{4}{c}{ Composition (\%) } \\
\cline { 3 - 6 } & & Moisture & Volatile & Ashes & Fixed Carbon $^{*}$ \\
\multirow{3}{*}{ Palm } & Mean & 4.56 & 22.09 & 3.17 & 70.18 \\
& SD & 0.35 & 1.04 & 0.41 & 1.17 \\
& VC & 7.68 & 4.71 & 12.93 & 1.67 \\
\hline
\end{tabular}


of the carbonization process, as well as to improve the quality of produced charcoal, which can be observed in this work.

\section{CONCLUSION}

The results of analyses showed high levels of fixed carbon, structural carbon, lignin, volatile substances and low ash and moisture content, indicating the characteristics necessary to be used in the direct production of energy, production of activated carbon and also biochar.

\section{ACKNOWLEDGEMENTS}

To the Federal University of Lavras, to the Graduate Program in Wood Science and Technology, to the State University of Pará and to the Research Group Science, Wood Innovation and Technology in the Amazon for the opportunity to carry out this work.

\section{SUBMISSION STATUS}

Received: 14 nov., 2018

Accepted: 13 dec., 2018

\section{CORRESPONDENCE TO}

\section{João Rodrigo Coimbra Nobre}

Departamento de Tecnologia da Madeira DETM, Universidade do Estado do Pará - UEPA, Rodovia PA-124, s/n, Bairro Angelim, CEP 68625-000, Paragominas, PA, Brasil e-mail: rodrigonobre@uepa.br; rodrigonobre@ hotmail.com.br

\section{REFERENCES}

Associação Brasileira de Normas Técnicas - ABNT. NBR13999: determinação do resíduo (cinza) após a incineração a $525{ }^{\circ} \mathrm{C}$. Rio de Janeiro; 2003.

Associação Brasileira de Normas Técnicas - ABNT. NBR14853: determinação do material solúvel em etanol-tolueno e em diclorometano e acetona. Rio de Janeiro; 2010a.

Associação Brasileira de Normas Técnicas - ABNT. NBR7989: polpa celulósica e madeira: determinação de lignina insolúvel em ácido. Rio de Janeiro; 2010 b.

Brand MA, Giesel G. Influência da secagem da biomassa na eficiência de caldeira de cogeração energética. Energia na Agricultura 2017; 32(2): 132-140. http://dx.doi. org/10.17224/EnergAgric.2017v32n2p132-140.

Brito JO, Barrichelo LEG. Correlations between physical and chemical characteristics of wood and charcoal production: density and lignin content of eucalyptus wood. IPEF [online] 1977; 14: 9-20 [cited 2018 Nov 14]. Available from: http://www.ipef.br/publicacoes/scientia/ nr14/cap01.pdf

Castro JP. Production and physical characterization of activated carbons from pre-treated piaçava fibers [tese]. Lavras: Departamento de Ciência e Tecnologia da Madeira, Universidade Federal de Lavras; 2016.

Cheng WP, Gao W, Cui X, Ma JH, Li RF. Phenol adsorption equilibrium and kinetics on zeolite $\mathrm{X} /$ activated carbon composite. Journal of the Taiwan Institute of Chemical Engineers 2016; 62: 192-198. http://dx.doi.org/10.1016/j. jtice.2016.02.004.

Demiral H, Demiral İ, Karabacakoğlu B, Tümsek F. Production of activated carbon from olive bagasse by physical activation. Chemical Engineering Research \& Design 2011; 89(2): 206-213. http://dx.doi.org/10.1016/j. cherd.2010.05.005.

Ekinci K. Utilization of apple pruning residues as a source of biomass energy: a case study in Isparta province. Energy Exploration \& Exploitation 2011; 29(1): 87-107. http:// dx.doi.org/10.1260/0144-5987.29.1.87.

Esteves MRL, Abud AKS, Barcellos KM. Evaluation of the potential energy of green coconut shells for achievement in production of briquetes. Scientia Plena [online] 2015; 11(3): 1-8 [cited 2018 Nov 14]. Available from: https:// www.scientiaplena.org.br/sp/article/view/2230/1151

Hameed Khan H, Krishnakumar V. Soil productivity and nutrition. In: Nampoothiri KUK, Krishnakumar V, Thampan PK, Achuthan Nair M, editors. The coconut palm (Cocos nucifera L.): research and development perspectives. Singapore: Springer; 2018. p. 323-442. http://dx.doi. org/10.1007/978-981-13-2754-4_8.

Hamza UD, Nasri NS, Amin NAS, Mohammed J, Zain HM. Characteristics of oil palm shell biochar and activated carbon prepared at different carbonization times. Desalination and Water Treatment 2016; 57(17): 7999-8006. http:// dx.doi.org/10.1080/19443994.2015.1042068.

Huang C, Han L, Yang Z, Liu X. Ultimate analysis and heating value prediction of straw by near infrared spectroscopy. Waste Management 2009; 29(6): 1793-1797. http://dx.doi. org/10.1016/j.wasman.2008.11.027. PMid:19138837.

Linhares FA, Marcílio NR, Melo PJ. Study of activated carbon production from the black wattle shell waste with and without chemical activation. Scientia Cum Industria 2016; 4(2): 74-79.

Luk HT, Lam TYG, Oyedun AO, Gebreegziabher T, Hui CW. Drying of biomass for power generation: a case study on power generation from empty fruit bunch. 
Energy 2013; 63: 205-215. http://dx.doi.org/10.1016/j. energy.2013.10.056.

Machado FS, Andrade AZ. Thermo-chemical properties of charcoal fines and mineral coal for the injection into the blast furnaces of steel blast furnaces. Biomass \& Energy 2004; 1(4): 353-363.

Moulin JC, Nobre JRC, Castro JP, Trugilho PF, Arantes MDC. Effect of extractives and carbonization temperature on energy characteristics of wood waste in Amazon rainforest. Cerne 2017; 23(2): 209-218. http://dx.doi.or g/10.1590/01047760201723022216.

Oasmaa A, Solantausta Y, Arpiainen V, Kuoppala E, Sipila K. Fast pyrolysis bio-oils from wood and agricultural residues. Energy \& Fuels 2010; 24(2): 1380-1388. http:// dx.doi.org/10.1021/ef901107f.

Protásio TP, Santana JDP, Guimarães RM No, Guimarães JB Jr, Trugilho PF, Ribeiro IB. Evaluation of charcoal quality of Qualea parviflora. Brazilian Journal of Forestry Research [online] 2011; 31(68): 295-307 [cited 2018 Nov 14]. Available from: https://pfb.cnpf.embrapa.br/pfb/ index.php/pfb/article/view/276/229

Saidur R, Abdelaziz EA, Demirbas A, Hossain MS, Mekhilef S. A review on biomass as a fuel for boilers. Renewable \& Sustainable Energy Reviews 2011; 15(5): 2262-2289. http://dx.doi.org/10.1016/j.rser.2011.02.015.

Sekirifa ML, Hadj-Mahammed M, Pallier S, Baameur L, Richard D, Al-Dujaili AH. Preparation and characterization of an activated carbon from a date stones variety by physical activation with carbon dioxide. Journal of Analytical and Applied Pyrolysis 2013; 99: 155-160. http://dx.doi. org/10.1016/j.jaap.2012.10.007.

Soares VC, Bianchi ML, Trugilho PF, Pereira AJP, Hofler J. Correlações entre as propriedades da madeira e do carvão vegetal de híbridos de eucalipto. Revista Árvore 2014; 38(3): 543-549. http://dx.doi.org/10.1590/S010067622014000300017.

Souza JEA, Paes FA Fo, Silva BPC, Tenório NVN, Sousa FJ, Almeida RM et al. Biomass residues as fuel for the ceramic industry in the state of Alagoas: brazil. Waste Biomass Value 2011; 3(2): 191-196. http://dx.doi.org/10.1007/ s12649-011-9100-8.

Tay T, Ucar S, Karagöz S. Preparation and characterization of activated carbon from waste biomass. Journal of Hazardous Materials 2009; 165(1-3): 481-485. http:// dx.doi.org/10.1016/j.jhazmat.2008.10.011. PMid:19022575.

Teixeira AM. Babassu: a new approach for an ancient Brazilian biomass. Biomass and Bioenergy 2008; 32(9): 857-864. http://dx.doi.org/10.1016/j.biombioe.2007.12.016.

Trugilho PF, Silva DA. Influence of the final carbonization temperature on the physical and chemical charcoal of jatobá (Himenea courbaril L.). Scientia Agraria 2001; 2(1-2): 45-53. http://dx.doi.org/10.5380/rsa.v2i1.976.

Vale AT, Gentil LV, Gonçalez JC, Costa AF. Caracterização energética e rendimento da carbonização de resíduos de grãos de café (Coffea arabica, L) e de madeira (Cedrelinga catenaeformis). Duke. Cerne 2007; 13(4): 416-420.

Vale AT, Santos ID, Santana MAE. Relationships among chemical properties, physical and energy wood properties of five Cerrado species. Ciência Rural [online] 2010; 20(1): 137-145 [cited 2018 Nov 14]. Available from: https:// periodicos.ufsm.br/cienciaflorestal/article/view/1767/0 Yang $H$, Yan $R$, Chen $H$, Zheng C, Lee DH, Liang DT. Influence of mineral matter on pyrolysis of palm oil wastes. Combustion and Flame 2006; 146(4): 605-611. http://dx.doi.org/10.1016/j.combustflame.2006.07.006. 